Relations industrielles

Industrial Relations

\title{
Aggarwal, Arjun P., Sexual Harassment in the Workplace
}

\section{P. Andiappan}

Volume 49, numéro 1, 1994

URI : https://id.erudit.org/iderudit/050931ar

DOI : https://doi.org/10.7202/050931ar

Aller au sommaire du numéro

Éditeur(s)

Département des relations industrielles de l'Université Laval

ISSN

0034-379X (imprimé)

1703-8138 (numérique)

Découvrir la revue

Citer ce compte rendu

Andiappan, P. (1994). Compte rendu de [Aggarwal, Arjun P., Sexual Harassment in the Workplace]. Relations industrielles / Industrial Relations, 49(1), 204-205.

https://doi.org/10.7202/050931ar

Tous droits réservés (C) Département des relations industrielles de l'Université Laval, 1994
Ce document est protégé par la loi sur le droit d'auteur. L'utilisation des services d'Érudit (y compris la reproduction) est assujettie à sa politique d'utilisation que vous pouvez consulter en ligne.

https://apropos.erudit.org/fr/usagers/politique-dutilisation/ 
Sexual Harassment in the Workplace, 2d ed., by Arjun P. AgGaRwal, Toronto, Butterworths, 1992, 385 p., ISBN 0-409-90670-0

Since the first edition of Aggarwal's Sexual Harassment in the Workplace came out in 1987, several major developments in this area have occurred. These include two Supreme Court decisions on the subject, remedies for the victims of sexual harassment under the Worker's Compensation Act, entitlement to unemployment insurance benefits on being fired or leaving a job due to sexual harassment, obligations of the employer to the alleged harasser and the extent of a union's liability for sexual harassment of employers. We are glad to have the second edition of this book which includes discussions on these new developments and other matters which are relevant to the understanding of the topical issues of the 90's. As expected, the second edition of this book is thicker in size and more comprehensive in content.

The first chapter is devoted to a lengthy discussion of the concept of sexual harassment under the various human rights codes in Canada. The chapter also includes a narrative history of the development of sexual harassment law in the U.S. and in Canada. This is followed in the second chapter by a crisp explanation of the definitions of sexual harassment as espoused by the Canadian Supreme Court in Janzen v. Platy Enterprises Ltd. [1989]. An interesting addition to this chapter is the discussion of sex based harassment - sexual references or comments which do not amount to sexual advances or solicitations but nevertheless, causing harassment if they are pervasive. It is held that making fun of one's gender based characteristics or taunting or teasing or making demeaning comments based on one's gender interferes with the employee's right to work in an environment free of sexual harassment. In this context, it is relevant to keep in mind that men often have the collective ability to determine the environment in which women work and that this source of male power should be recognized.

Chapter three contains a lengthy discussion of the nature of proof required in sexual harassment cases which is of interest to practising lawyers. Chapter four, on the other hand, is of considerable importance for human resource managers and union officials since it contains a discussion of the employer's liability for the discriminating conduct of supervisory employees, co-workers and non-employees. Aggarwal extended his investigation and discussion in chapter 5 to include workers' compensations benefits and unemployment insurance benefits. Only recently did the legislatures and courts realize the need to recognize that sexual harassment may cause psychiatric disorder making the employee unable to perform her/his job functions or that employees who lose or quit these jobs because of sexual harassment are entitled to unemployment benefits.

The use of grievance arbitration to provide remedies for sexual harassment is an important aspect which need a lengthy discussion. Recognizing this, Aggarwal has added a new chapter devoted exclusively to the arbitral review of sexual harassment cases. The author's analysis of the arbitrations decisions is exemplary and is useful for both the unions and management.

The last two chapters of the book are devoted to discussions on the prevention of sexual harassment and union's role in it. The author emphasizes that prevention of sexual harassment does not lie in lip service but in establishing and implementing policies and procedures with everyone in the organization committed to its success. 
In summary, the second edition of Aggarwal's book is a worthwhile addition to any human resource professional's library.

P. ANDiappan

University of Windsor

Through Jaundiced Eyes : How the Media View Organized Labor, by William J. PueTTE, Ithaca, NY, ILR Press, 1992, 228 p., ISBN 0-87546-185-9

This well-researched book on media's treatment and portrayal of labour is both timely and useful. The importance of mass media as a sometimes silent, sometimes noisy player in the industrial relations system has grown over the years. Yet, formal analysis of its role in the system has not received the scruitiny that its growing importance suggests.

Puette focuses on media's treatment of labour rather than on media's role in the industrial relations system as a whole. He asks both the pertinent questions: is there a bias in the media against labour and, if yes, what may be the underlying causes? The first question comes out of a long research tradition which goes back to radio broadcasts of the 1920s. There is general agreement among most studies that media is prone to distortions, whether intended or not, that are unfavourable to labour interests.

What distinguishes this book from others in answering the question of bias is its comprehensive treatment of several forms of mass media. Chapter One deals with movies, Chapter Two with television news, Chapter Three with television dramas, Chapter Four with newspapers, and Chapter Five with cartoons. Chapters Six and Seven present two in-depth case studies on specific labour events covered by the media. The first case is that of a dispute between a Maui construction contractor and the Carpenters Union. Newspaper reports taken from three Hawaii newspapers between 1983 and 1986 form the basis for this part of the analysis. The second case is that of the Mine Workers' strike against the Pittston Company in 1989-90. Chapter Eight deals with labour's response to this bias. Chapter Nine, the last Chapter, provides a summary and an analytical synthesis.

Apart from the main chapters, the book also offers a rich database for researchers in the appendices. Appendix B provides a detailed list of American movies in which labour was a major theme. Appendix $C$ similarly provides a list of TV network news specials and TV documentaries about labour unions. Appendix D contains plot synopses of TV dramas.

In each chapter, themes, dialogues, musings, and commentaries that appear ordinary to the lay eye, are carefully deconstructed for their impact on labour's image and interests. Puette uses Cirino's (1971) "catalogue of hidden bias" as a guide for this analysis. Cirino's work was aimed at discovering media bias in general which is cleverly adapted to the question of bias against labour. Another analytical technique used in the book is Parenti's (1986) seven basic generalizations that typify medias treatment of labour. These analytical frameworks are used to examine each form of mass media. 